\title{
Kajian Awal Pemanfaatan Anodizing Technique Untuk Meningkatkan Laju Alir Keramik Berbasis Pasir Silika
}

Doni Mawenaa, Asifa Asria, Mariana B. Malinoa*,

aProdi Fisika, FMIPA Universitas Tanjungpura

Jalan Prof. Dr. Hadari Nawawi, Pontianak, Indonesia

*Email : marianamalino9@gmail.com

\begin{abstract}
Abstrak
Penelitian yang telah dilakukan bertujuan untuk memodifikasi pori keramik berpori berbahan dasar pasir silika dan lempung menggunakan anodizing technique. Pembuatan keramik dilakukan secara manual dengan pengeringan selama 5 hari dan pembakaran pada suhu $945^{\circ} \mathrm{C}$ serta penahanan selama 2 jam. Setelah proses fabrikasi, dilakukan proses anodizing dengan lima variasi waktu yaitu 10 menit, 15 menit, 20 menit, 25 menit, dan 30 menit dengan menggunakan tegangan 20 volt serta kerapatan arus 25 $\mathrm{mA} / \mathrm{cm}^{2}$. Hasil penelitian menunjukkan nilai porositas dan laju alir keramik mengalami peningkatan masing-masing dalam rentang 0,39\% hingga 0,66\% dan 6,67\% hingga 8,87\% setelah diberi perlakuan anodizing. Keramik dengan lama waktu anodizing 20 menit menghasilkan nilai porositas dan laju alir optimum yakni 32,37\% dan 0,159 mL/menit.
\end{abstract}

Kata kunci: keramik, lempung, pasir silika, porositas, laju alir, anodizing technique

\section{Latar Belakang}

Silika merupakan senyawa kimia dengan rumus $\mathrm{SiO}_{2}$ (silicon dioxide) yang dapat diperoleh dari mineral silika dan nabati. Mineral silika banyak ditemui dalam bahan tambang/galian yang berupa mineral seperti pasir kuarsa, granit dan fledsfar. Pasir silika telah banyak dikembangkan dalam berbagai bidang terutama pada bidang material dan juga sebagai cetakan untuk teknik pengecoran; bahkan sekarang pasir silika digunakan sebagai penopang membran keramik berpori [1].

Penelitian mengenai keramik berpori berbasis lempung dengan pasir silika sebagai penopang untuk mengadsorpsi kandungan besi (Fe) dalam air tanah telah dilakukan sebelumnya. Hasil penelitian tersebut menunjukkan bahwa ada peningkatan porositas sebesar 4,86\% untuk keramik yang diberi penopang pasir silika dibandingkan tanpa penopang pasir silika. Meskipun difungsikan sebagai penopang, pasir silika pada penelitian juga dapat bertindak sebagai adsorben Fe. Efektivitas adsorpsi $\mathrm{Fe}$ oleh keramik tanpa penopang pasir silika sebesar 76,04\%, sedangkan keramik dengan penopang pasir silika sebesar 98,75\% [1].

Kapasitas adsorpsi pasir silika untuk membantu adsorpsi pada lempung dapat ditingkatkan dengan memodifikasi pori-pori pasir silika. Untuk meningkatkan porositas dan laju alir maka digunakan anodizing technique supaya menghasilkan pori-pori pada pasir silika [2].
Proses anodizing technique pernah dilakukan oleh peneliti terdahulu antara lain proses anodizing untuk mengatur pori anodik alumina pada paduan AA1050 dan aluminium foil dengan menggunakan $0,3 \mathrm{M} \mathrm{H}_{2} \mathrm{SO}_{4}$ (asam sulfat) dan $0,3 \mathrm{M} \mathrm{C}_{2} \mathrm{H}_{2} \mathrm{O}_{4}$ (asam oksalat) pada masing-masing tegangan 25 volt dan 40 volt. Hasil penelitian menunjukkan bahwa rerata diameter pori pada paduan AA1050 sebesar $16,65 \mathrm{~nm}$ sedangkan pada substrat Al murni sebesar 18,78 nm [3].

Anodizing technique belum pernah diterapkan untuk memodifikasi pori pada keramik yang berbahan baku pasir silika, tetapi kadar silika yang tinggi dalam pasir yakni 96,06\% memungkinkan keberhasilan anodizing technique pada keramik tersebut [4]. Dengan demikian, pada penelitian yang dilakukan diterapkan anodizing technique pada keramik berbahan dasar pasir silika dan lempung untuk memodifikasi pori dengan variasi waktu saat proses anodizing selama 10 menit, 15 menit, 20 menit, 25 menit, dan 30 menit.

Berdasarkan uraian di atas, tujuan dari penelitian yang dilakukan, yaitu untuk membuat dan menganalisis keramik berpori dari pasir silika dan lempung. Keramik berpori dianalisis dari pengaruh waktu pada saat dilakukan anodizing terhadap porositas dan laju alir.

\section{Metodologi}

Alat-alat yang digunakan pada penelitian yaitu neraca digital, ayakan 40 mesh, botol vial $100 \mathrm{~mL}$, beaker glass $250 \mathrm{~mL}$, tanur, mold (bola plastik berdiameter $6,4 \mathrm{~cm}$ ), XRF (X-Ray 
Fluorescence), jangka sorong, mortar, wadah plastik, dan gelas ukur. Bahan-bahan yang digunakan pada penelitian adalah pasir silika 36,9 gram, lempung 24,6 gram, $\mathrm{HCl} 0,2 \mathrm{M}$, larutan gula $1,8 \mathrm{M}$, kertas lakmus, dan akuades.

\section{Pembuatan Keramik}

Preparasi bahan baku dimulai dengan menghaluskan lempung dan pasir silika menggunakan mortar hingga berbentuk serbuk kemudian diayak dengan ayakan 40 mesh. Pasir silika dan lempung yang telah berbentuk serbuk dicampur secara manual hingga homogen.

Sampel keramik dibentuk setengah bola secara manual menggunakan mold bola plastik dengan diameter $6,4 \mathrm{~cm}$ dan tebal sampel keramik yang dibuat yaitu 0,3 cm. Sampel keramik yang sudah agak mengeras dikeluarkan dari mold bola plastik kemudian dikeringkan di ruang terbuka selama 5 hari. Sampel keramik kemudian dibakar menggunakan tanur dengan pemanasan awal sampel hingga mencapai suhu $100^{\circ} \mathrm{C}$ dengan rentang $2^{\circ} \mathrm{C} /$ menit. Keramik dibakar selama 3 jam dengan rentang $5^{\circ} \mathrm{C} /$ menit untuk mencapai suhu $945^{\circ} \mathrm{C}$ [5]. Pada keramik kemudian dilakukan holding time (penahanan) selama 2 jam. Pendinginan dilakukan secara perlahan-lahan, dengan membiarkan keramik tetap di dalam tanur selama 12 jam.

\section{Anodizing Technique Pada Keramik}

Karakterisasi keramik yang sudah dibakar sebelum pelaksanaan proses anodizing meliputi uji susut bakar, porositas, dan laju alir. Setelah karakterisasi awal, keramik selanjutnya diberi perlakuan anodizing. Proses anodizing dilakukan dengan tujuan untuk membentuk pori-pori pada keramik. Keramik dan platina dimasukkan ke dalam wadah yang sudah berisi $\mathrm{HCl}$ dan keramik hanya tercelup sebagian terlihat seperti pada Gambar 1. Keramik sebagai kutub positif dan platina sebagai kutub negatif masing-masing dihubungkan dengan kawat tembaga sebagai konektor, kemudian dihubungkan dengan power supply pada tegangan 20 volt. Proses anodizing dilakukan dengan lima variasi waktu, yaitu 10 menit, 15 menit, 20 menit, 25 menit, dan 30 menit dengan kerapatan arus $25 \mathrm{~mA} / \mathrm{cm}^{2}$. Setelah proses anodizing selesai, keramik kemudian dicuci dengan air sampai $\mathrm{pH}$ netral dan dikeringkan di ruang terbuka selama 2 hari. Keramik yang telah diberi perlakuan anodizing kemudian dikarakterisasi untuk menguji porositas dan laju alir.

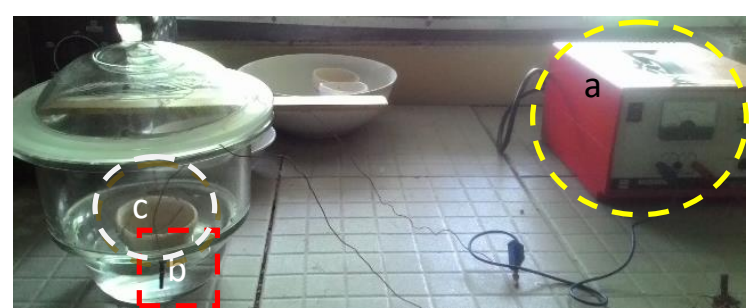

Gambar 1. Rangkaian sistem anodizing(a. Power supply; b. Platina; dan c. Keramik)

\section{Karakterisasi Sampel}

Bahan baku berupa lempung dan pasir silika yang digunakan dalam proses fabrikasi di analisis menggunakan XRF untuk melihat senyawa penyusun dari masing-masing bahan. Karakterisasi yang dilakukan pada sampel keramik meliputi susut bakar (susut massa dan susut volume), porositas dan laju alir.

Susut massa dihitung dengan persamaan (1).

$$
\% \text { susut massa }=\frac{m_{0}-m_{1}}{m_{0}} \times 100 \%
$$

Keterangan :

$m_{0}=$ massa sebelum dibakar (gram)

$m_{1}=$ massa sesudah dibakar (gram)

Susut bakar dihitung dengan persamaan (2).

$$
\% \text { susut volume }=\frac{V_{0}-V_{1}}{V_{0}} \times 100 \%
$$

Keterangan :

$V_{\mathrm{o}}=$ volume sebelum dibakar $\left(\mathrm{cm}^{3}\right)$

$V_{1}=$ volume sesudah dibakar $\left(\mathrm{cm}^{3}\right)$

Porositas dihitung dengan persamaan (3).

$$
p=\left(\frac{B-a}{B-c}\right) 100 \%
$$

Keterangan :

$p=$ porositas $(\%)$.

$B$ = Massa basah (gram)

$a$ = Massa kering (gram)

$c$ = Massa gantung (gram)

Laju alir dihitung dengan persamaan (4).

$$
Q=\frac{V_{F}}{t}
$$

Keterangan :

$$
\begin{array}{ll}
Q & =\text { laju filtrasi (mL/menit) } \\
V_{F} & =\text { volume air hasil filtrasi }(\mathrm{mL}) \\
t & =\text { waktu filtrasi (menit) }
\end{array}
$$

3. Hasil dan Pembahasan Analisis Komposisi Bahan Kimia Dan Fabrikasi Keramik 
Tabel 1. Komposisi kimia lempung dan pasir silika

\begin{tabular}{ccc}
\hline \multirow{2}{*}{ Senyawa } & \multicolumn{2}{c}{ Komposisi Berat $(\%)$} \\
\cline { 2 - 3 } & Lempung & Pasir silika \\
\hline $\mathrm{SiO}_{2}$ & 53,2 & 99,2 \\
$\mathrm{Al}_{2} \mathrm{O}_{3}$ & 31,6 & - \\
$\mathrm{TiO}_{2}$ & 5,59 & 0,17 \\
$\mathrm{Fe}_{2} \mathrm{O}_{3}$ & 5 & 0,066 \\
$\mathrm{NiO}$ & 0,11 & 0,01 \\
$\mathrm{CuO}$ & 0,076 & 0,038 \\
$\mathrm{CaO}$ & 0,55 & 0,45 \\
$\mathrm{Yb}_{2} \mathrm{O}_{3}$ & - & 0,04 \\
\hline
\end{tabular}

Berdasarkan hasil analisis XRF pada Tabel 1, diketahui bahwa sampel pasir silika yang digunakan sebagian besar tersusun atas senyawa silika dengan kadar senyawa silika $\left(\mathrm{SiO}_{2}\right)$ sebesar 99,2\%, sedangkan sampel lempung yang digunakan tersusun oleh bahan alumina silika dengan senyawa $\mathrm{SiO}_{2}$ sebesar $53,2 \%$ dan senyawa $\mathrm{Al}_{2} \mathrm{O}_{3}$ sebesar $31,6 \%$. Lempung dalam penelitian yang dilakukan, difungsikan sebagai perekat tambahan untuk membantu larutan gula mengikat partikelpartikel pasir silika.

Proses pengeringan awal selama 5 hari setelah keramik dibentuk, bertujuan untuk menghilangkan kandungan air dari dalam badan keramik terutama yang berada di bagian permukaan keramik. Pembakaran keramik dilakukan pada suhu $945^{\circ} \mathrm{C}$ setelah proses pengeringan, bertujuan menghilangkan sisa kandungan air dan menghasilkan pori-pori pada keramik [1]. Proses pembakaran keramik dilakukan dengan menaikkan suhu secara bertahap dengan heating rate $2^{\circ} \mathrm{C} /$ menit yang bertujuan untuk menghindari keretakan akibat tekanan uap air maupun penyusutan secara mendadak.

Keramik yang dihasilkan dengan komposisi 36,9 gram pasir silika dan 24,6 gram lempung memiliki kecerahan warna yang seragam seperti ditunjukkan pada Gambar 2.

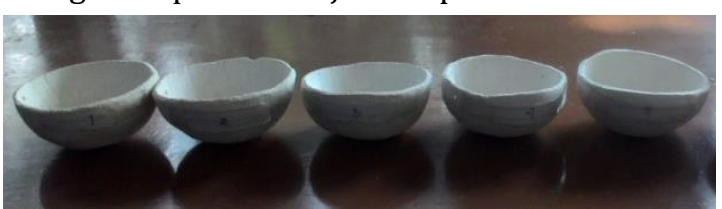

Gambar 2. Keramik setelah pembakaran pada suhu $945^{\circ} \mathrm{C}$

\section{Pengaruh Anodizing Terhadap Porositas}

Porositas merupakan volume ruang kosong yang direpresentasikan sebagai jumlah massa atau volume air yang terserap pada material keramik. Pengukuran porositas keramik dilakukan menggunakan teknik perendaman dan persentase porositas dihitung menggunakan Persamaan 3. Penentuan porositas keramik dilakukan sebelum anodizing dan setelah anodizing untuk melihat pengaruh anodizing terhadap porositas keramik.

Perbedaan nilai porositas setiap sampel keramik sebelum anodizing tidak signifikan sehingga dapat dianggap bahwa kondisi awal sampel sama. Perbedaan kecil yang terjadi bersumber dari proses pemadatan (densifikasi) yang tidak seragam yang diduga akibat pengaruh posisi lokasi air yang berbeda-beda dalam badan keramik sehingga menyebabkan laju pengeringan berbeda-beda untuk setiap sampel.

Porositas keramik setelah anodizing mengalami peningkatan dalam rentang 0,39\% hingga $0,66 \%$ dibandingkan porositas sebelum anodizing. Peningkatan nilai porositas mengindikasikan bahwa setelah anodizing, poripori menjadi lebih teratur.

Perbandingan antara porositas sebelum dan sesudah anodizing ditunjukkan pada grafik dalam Gambar 3. Berdasarkan Gambar 3, peningkatan porositas optimum dihasilkan dari sampel yang mengalami perlakuan anodizing selama 15 menit yaitu sampel 2 .

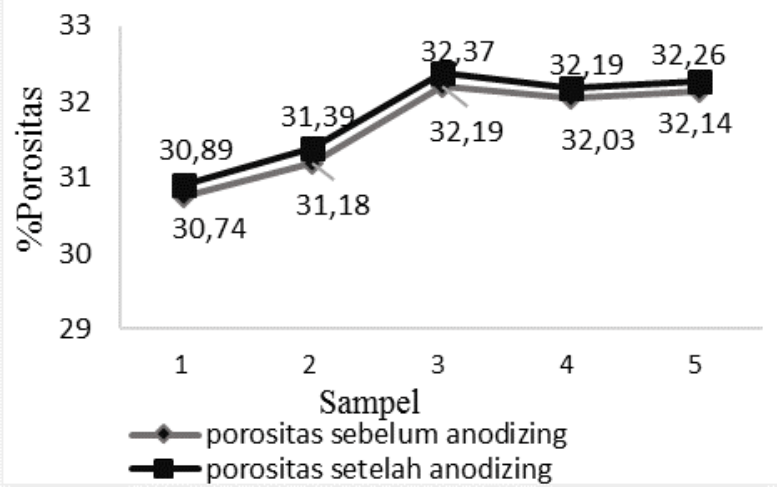

Gambar 3. Grafik perbandingan porositas sebelum dan sesudah anodizing

Berdasarkan variasi lama waktu anodizing yang digunakan, porositas optimum diperoleh dari sampel 3 dengan waktu anodizing selama 20 menit. Sampel 4 dengan lama waktu anodizing 25 menit dan sampel 5 dengan lama waktu anodizing 30 menit mengalami penurunan porositas. Hal tersebut diduga akibat penambahan tumpukan lapisan oksida di sekitar pori dan dalam badan keramik. Namun demikian, berdasarkan Gambar 4, terlihat ada kecenderungan peningkatan porositas seiring pertambahan lama waktu anodizing. 


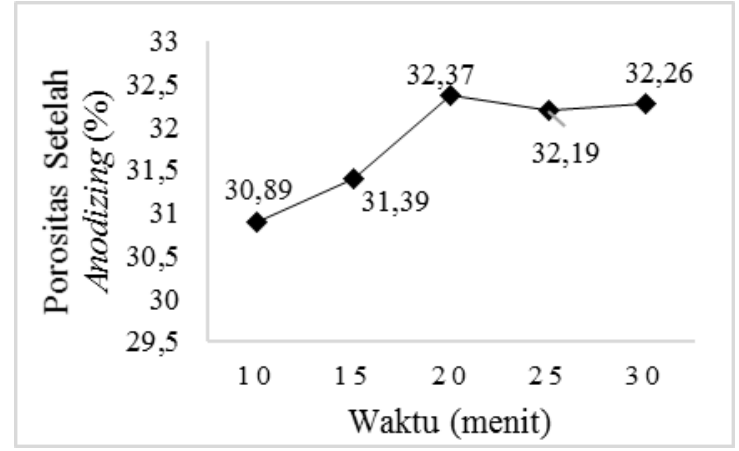

Gambar 4. Grafik nilai porositas setelah anodizing terhadap waktu

\section{Pengaruh Anodizing Terhadap Laju Alir}

Pengujian laju alir bertujuan untuk mengetahui kemampuan keramik dalam meloloskan partikel air pada rentang waktu tertentu. Proses pengukuran laju alir ditunjukkan pada Gambar 5.

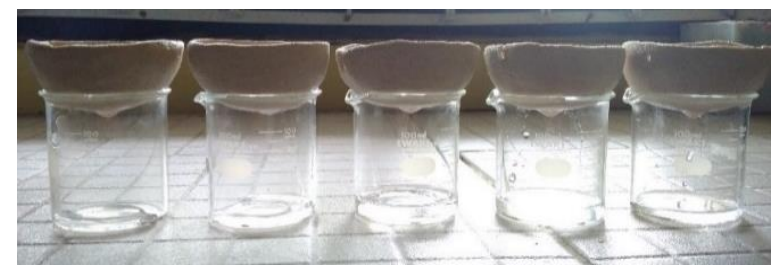

Gambar 5. Proses pengujian laju alir

Laju alir sebelum anodizing mengalami peningkatan pada setiap sampel, namun pada saat sampel 4 diuji laju alir yang dihasilkan mengalami penurunan kemudian pada sampel 5 laju alir yang dihasilkan mengalami peningkatan. Penurunan nilai laju alir diindikasikan karena ada beberapa pori-pori keramik yang tertutup oleh lapisan oksida serta akibat pemadatan sampel keramik yang berpengaruh pada keadaan awal pori.

Laju alir keramik setelah dilakukan anodizing mengalami peningkatan dibandingkan laju alir keramik sebelum dilakukan anodizing. Peningkatan nilai laju alir setelah dilakukan anodizing menunjukkan bahwa proses anodizing mempengaruhi laju alir keramik. Selisih peningkatan laju alir pada setiap sampel keramik setelah dilakukan anodizing berkisar antara 6,67\% hingga 8,87\% dengan laju alir optimum diperoleh dari sampel 3. Peningkatan laju alir pada keramik mengindikasikan bahwa semakin lama proses anodizing akan menyebabkan perubahan pada pori-pori berupa peningkatan ukuran dan keteraturan pori. Peningkatan ukuran dan keteraturan pori bersumber dari aktivitas ion $\mathrm{H}^{+}$yang menyebabkan pelepasan massa kandungan senyawa-senyawa dalam keramik. Reduksi massa tersebut menghasilkan peningkatan ukuran pori yang diikuti dengan kondisi pori menjadi lebih teratur. Laju alir keramik sebelum dan sesudah anodizing ditunjukkan pada grafik gambar 6.

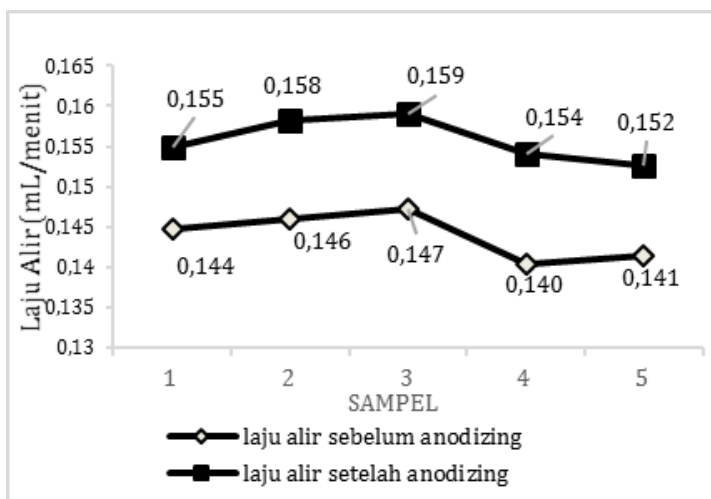

Gambar 6. Grafik perbandingan nilai laju alir sebelum dan sesudah anodizing

Berdasarkan variasi waktu yang diterapkan pada saat proses anodizing seperti ditunjukkan pada Gambar 7, ada kecenderungan peningkatan nilai laju alir seiring pertambahan lama waktu anodizing. Penurunan laju alir pada sampel 4 dan 5 diduga bersumber dari penebalan lapisan oksida yang bertambah seiring pertambahan waktu anodizing.

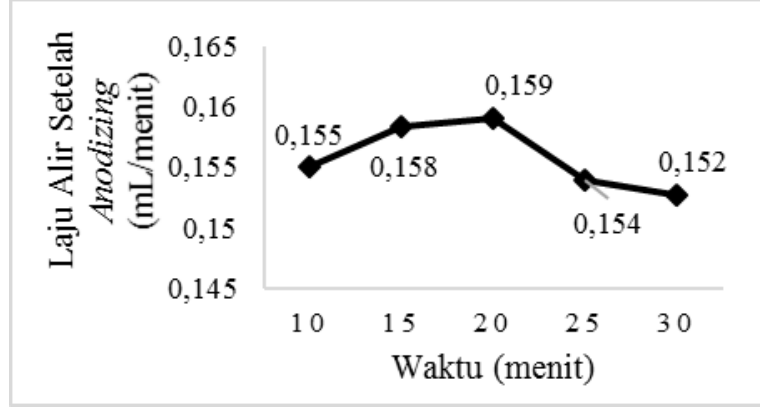

Gambar 7. Grafik nilai laju alir setelah anodizing terhadap waktu

\section{Kesimpulan}

Berdasarkan penelitian yang telah dilakukan, maka dapat disimpulkan bahwa keramik berpori berbahan dasar pasir silika dan lempung setelah melalui proses anodizing mengalami peningkatan nilai porositas $0,39 \%$ hingga $0,66 \%$ dan sebanding dengan nilai laju alir yang mengalami peningkatan sekitar 6,67\% hingga 8,87\%. Keramik dengan lama waktu anodizing 20 menit menghasilkan nilai porositas dan laju alir optimal yakni $32,37 \%$ dan 0,159 $\mathrm{mL} /$ menit.

\section{Ucapan Terima Kasih}

Penulis mengucapkan terimakasih kepada COMDEV \& OUTREACHING UNTAN yang telah mendanai riset. 


\section{Daftar Pustaka}

1. Ridayani D. Analisis Porositas dan Susut Bakar keramik Berpori Berbasis Clay dan Serat Tandan Kosong Kelapa Sawit. Jurnal PRISMA FISIKA UNTAN; V. 2017.

2. Zaraska, G. D. Anodic alumina membranes with defined pore diameters and thicknesses obtained by adjusting the anodizing duration and pore opening/widening time. J Solid State Electrochem. 2011

3. Zaraska L, et al. Porous Anodic Alumina Formed by Anodization of Aluminum Alloy (AA1050) and High Purity Aluminum. Elsevier. 2010.

4. Sumarno, P. N. Pemurnian Pasir Silika dengan Metode Leaching Asam dan bantuan Sonikasi. jurnal penelitian, 2. 2015.

5. Chemani, H., \& Chemani, B. Valorization of Wood Sawdust in Making Porous Clay Brick. Scientific Research and Essays, 8(15), 609-614. 2013. 